\title{
PELATIHAN KADER POSYANDU BALITA DI WILAYAH KERJA PUSKESMAS SUNGAI RANGIT
}

\author{
Rahaju Ningtyas ${ }^{1}$ Isnina $^{2}$ Yogie Irawan ${ }^{3}$ \\ ${ }^{123}$ STIKes Borneo Cendekia Medika Pangkalan Bun \\ ${ }^{3}$ Email : masyuduk@gmail.com
}

\begin{abstract}
ABSTRAK
Kesehatan ibu dan anak merupakan salah satu aspek yang prioritas untuk diperhatikan. Masa depan anak sangat ditentukan oleh kesehatan sejak dalam kandungan dan pada masa balitanya. Kesehatan ibu hamil perlu diperhatikan mengingat masih banyaknya kejadian komplikasi pada kehamilan dan persalinan yang akan berdampak pada kesehatan bayi yang dilahirkannya. Begitu pula kemampuan perawatan bayi baru lahir. Metode pendekatan yang akan dipakai untuk menyelesaikan persoalan mitra yaitu dengan memberikan rangkaian kegiatan pelatihan untuk pengelolaan posyandu dan pelatihan memberikan penyuluhan kesehatan kepada masyarakat. Praktek kemampuan penyuluhan kader ini juga akan dilombakan untuk mengetahui kemampuan kader dari hasil pelatihan. Metode yang digunakan dalam pengabdian masyarakat ini yaitu dengan pemberian kegiatan pelatihan-pelatihan untuk peningkatan skill kader posyandu disertai dengan mengadakan lomba penyuluhan efektif kepada masyarakat. Pemenang kegiatan lomba posyandu ini diberikan hadiah berupa uang pembinaan untuk melengkapi sarana pra sarana yang menunjang kegiatan posyandu masing masing. Melalui kegiatan ini diharapkan peran posyandu sebagai ujung tombak pemantauan kesehatan di masyarakat dapat lebih optimal.
\end{abstract}

Kata kunci : Lansia

\section{POSYANDU KADER TRAINING FOR CHILDREN IN RANGIT RIVER HEALTH CENTER WORKING AREA}

\begin{abstract}
Maternal and child health is one of the priority aspects to consider. The future of a child is very much determined by his health from the womb and his toddler. The health of pregnant women needs to be considered given that there are still many complications in pregnancy and childbirth that will have an impact on the health of the baby being born. Similarly, the ability to care for newborns. The approach method that will be used to solve partner problems is by providing a series of training activities for posyandu management and training in providing health education to the community. The practice of cadre extension services will also be contested to find out the cadre's abilities from the training results. The method used in this community service is by providing training activities to improve the skills of posyandu cadres accompanied by holding effective counseling competitions to the community. The winner of the posyandu competition is given a prize in the form of
\end{abstract}


coaching money to complement the pre-facilities that support each posyandu activity. Through this activity it is hoped that the role of the posyandu as the spearhead of health monitoring in the community can be more optimal.

Keywords: Elderly

\section{PENDAHULUAN}

Kesehatan ibu dan anak merupakan salah satu aspek yang prioritas untuk diperhatikan. Masa depan anak sangat ditentukan oleh kesehatan sejak dalam kandungan dan pada masa balitanya. Kesehatan ibu hamil perlu diperhatikan mengingat masih banyaknya kejadian komplikasi pada kehamilan dan persalinan yang akan berdampak pada kesehatan bayi yang dilahirkannya. Begitu pula kemampuan perawatan bayi baru lahir.

Jumlah pengurus kader masihlah sedikit, sehingga keberadaan posyandu sangat membantu mereka dalam pemantauan kesehatan balita. Sayangnya fasilitas peralatan posyandu masih minimal dan proses pencataan hasil pemantauan kesehatan masih sangat manual sehingga pihak puskesmas tidak cepat mengakses dan memberikan respon bila ada masalah kesehatan terhadap ibu dan balita. Disamping itu tingkat pendidikan kader tidak ada yang memiliki latar belakang pendidikan kesehatan. Oleh karena itu dalam pelaksanaan program kegiatan posyandu masih sangat perlu untuk pembinaan. Pelaksanaan posyandu juga masih mengalami beberapa kendala antara lain kemampuan kader yang masih kurang dalam kegiatan penimbangan dan pengukuran tinggi badan balita, kemampuan kader yang kurang dalam menginterpretasikan hasil pengukuran status gizi dan peran masyarakat yang kurang sehingga berimbas pada cakupan balita yang ditimbang kurang dari target yang ditetapkan.
Kader kesehatan adalah tenaga yang berasal dari masyarakat yang dipilih oleh masyarakat dan bekerja bersama untuk masyarakat secara sukarela (Mantra, 1983). Kader kesehatan masyarakat adalah laki-laki atau wanita yang dipilih oleh masyarakat dan dilatih untuk menanggani masalah-masalah kesehatan perseorangan maupun masyarakat setra untuk bekerja dalam hubungan yang amat dekat dengan tempat- tempat pemberian pelayanan kesehatan (WHO, 1995). Kader sebagai warga masyarakat setempat yang dipilih dan ditinjau oleh masyarakat dan dapat bekerja secara sukarela. Kader secara sukarela bersedia berperan melaksanakan dan mengelola kegiatan keluarga berencana di desa (Karwati, dkk, 2009).

Balita adalah anak dengan usia dibawah 5 tahun dengan karakteristik pertumbuhan cepat pada usia 0-1 tahun, dimana umur 5 bulan berat badan naik 2 kali berat badan lahir dan berat badan naik 3 kali dari berat badan lahir pada umur 1 tahun dan menjadi 4 kali pada umur 2 tahun. Pertumbuhan mulai lambat pada masa pra sekolah kenaikan berat badan kurang lebih $2 \mathrm{~kg}$ per tahun, kemudian pertumbuhan konstan mulai berakhir (Soetjiningsih, 2001). Balita merupakan masa pertumbuhan tubuh dan otak yang sangat pesat dalam pencapaian keoptimalan fungsinya, pertumbuhan dasar yang akan mempengaruhi serta menentukan perkembangan kemampuan berbahasa, 
kreatifitas, kesadaran sosial, emosional dan intelegensia (Supartini, 2004).

\section{METODE PENELITIAN}

Metode pendekatan yang akan dipakai untuk menyelesaikan persoalan mitra yaitu dengan memberikan rangkaian kegiatan pelatihan untuk pengelolaan posyandu dan pelatihan memberikan penyuluhan kesehatan kepada masyarakat. Praktek kemampuan penyuluhan kader ini juga akan dilombakan untuk mengetahui kemampuan kader dari hasil pelatihan.

\section{HASIL DAN PEMBAHASAN}

Metode yang digunakan dalam pengabdian masyarakat ini yaitu dengan pemberian kegiatan pelatihan-pelatihan untuk peningkatan skill kader posyandu disertai dengan mengadakan lomba penyuluhan efektif kepada masyarakat. Pemenang kegiatan lomba posyandu ini diberikan hadiah berupa uang pembinaan untuk melengkapi sarana pra sarana yang menunjang kegiatan posyandu masing masing. Melalui kegiatan ini diharapkan peran posyandu sebagai ujung tombak pemantauan kesehatan di masyarakat dapat lebih optimal.

Hasil dari kegiatan ini meningkatkan kemampuan kader dalam memberikan penyuluhan kepada masyarakat dengan metode yang lebih menarik sehingga meningkatkan kepercayaan diri kader untuk bisa berbagi kepada masyarakat tentang kesehatan.

\section{KESIMPULAN DAN SARAN}

\section{Kesimpulan}

Setelah kegiatan program pengabdian kepada para kader dan masyarakat sekitar Puskesmas Sungai Rangit ini terlaksana, para kader dan masyarakat menjadi mengerti dan paham tentang pentingnya kesehatan dan pemeriksaan dini.

\section{Saran}

Dengan adanya kegiatan ini diharapkan adanya peningkatan pengetahuan yang signifikan antara sebelum dan setelah pelatihan dan meningkatnya skill.

\section{DAFTAR PUSTAKA}

Notoatmodjo, Soekidjo. 2003. Pendidikan Dan Perilaku Kesehatan. Rineka Cipta. Jakarta.

Sandjaja, 2009, Kamus Gizi. Jakarta: PT Kompas Media Nusantara.

Supartini. Buku ajar konsep dasar keperawatan anak. Jakarta. EGC

WHO, 1995. Department of Sustainable Development and Healthy Environments 